\title{
PENGARUH PEMBERIAN JUS APEL FUJI (MALUS DOMESTICA) DAN SUSU TINGGI KALSIUM RENDAH LEMAK TERHADAP KADAR KOLESTEROL TOTAL TIKUS SPRAGUE DAWLY HIPERKOLESTEROLEMIA
}

\author{
Partika Kharunia Dewi, Muhammad Sulchan") \\ Program Studi Ilmu Gizi Fakultas Kedokteran Universitas Diponegoro \\ J1.Dr.Sutomo No.18, Semarang, Telp (024) 8453708, Email : gizifk@ undip.ac.id
}

\begin{abstract}
Background: Cardiovascular disease is the leading causes of death in the world. One of the cardiovascular risk factor is hypercholesterolemic, signed by highness total cholesterol level in the blood. An appropriate management of total cholesterol level can reduce risks of cardiovascular disease. Apple and high calcium low fat milk may be beneficial for lowering total cholesterol levels in the blood. This study aims to get the information on the effect of fuji apple juice and high-calcium low fat milk on total cholesterol level in hypercholesterolemic Sprague Dawley rats.

Methods: This study was a true experiment with pre-post test randomized control group design towards 25 hypercholesterolemic rats which were randomized into 6 groups. There were negative control group that was only given standard diet, positive control group that were given standard and high cholesterol diet, and four treatment groups that were given standard and high cholesterol diet and combinations of peeled and unpeeled apple juice at dosages $4.62 \mathrm{~g}$ and high-calcium low fat milk at dosages $6.16 \mathrm{ml}$ for 14 days. Total cholesterol serum was measured by CHOD-PAP method before and after intervention. Data were analyzed by Paired t-test, Wilcoxon and Annova.

Result: Total cholesterol level in $K$ - group decrease from 51,8mg/dl to 50,3mg/dl whereas in $\mathrm{K}+$ group increase from 37,8mg/dl to 41,3mg/dl. The intervention resulted total cholesterol in P1, P3 and P4 groups decrease while total cholesterol in P2 group increase. Total cholesterol level in P1 group decrease from $51 \mathrm{mg} / \mathrm{dl}$ to 46,3mg/dl, P3 group 48,2 $\mathrm{mg} / \mathrm{dl}$ to $42,4 \mathrm{mg} / \mathrm{dl}$ and $\mathrm{P} 4$ group $46 \mathrm{mg} / \mathrm{dl}$ to $44 \mathrm{mg} / \mathrm{dl}$. total cholesterol level in P2 group increase from $50 \mathrm{mg} / \mathrm{dl}$ to $55,3 \mathrm{mg} / \mathrm{dl}$. Based on Annova test there was no significant difference was observed regarding total cholesterol level between all groups ( $p=0,224)$.

Conclusion: The administration of peeled and unpeeled apple juice at dosages $4.62 \mathrm{~g}$ and high-calcium low fat milk at dosages $6.16 \mathrm{ml}$ for 14 days can't reduce the total cholesterol level on rats.

Key words : fuji apple juice; high calcium low fat milk; total cholesterol; hypercholesterolemic
\end{abstract}

\begin{abstract}
ABSTRAK
Latar Belakang : Penyakit kardiovaskuler merupakan penyebab utama kematian di dunia. Salah satu faktor risiko terjadinya penyakit ini ialah hiperkolesterolemia yang ditandai oleh tinggi nya kadar kolesterol total dalam darah. Pengendalian kadar kolesterol total yang tepat dapat mengurangi risiko penyakit kardiovaskuler. Apel dan susu tinggi kalsium rendah lemak kemungkinan bermanfaat menurunkan kadar kolesterol total dalam darah. Penelitian ini bertujuan untuk mengetahui pengaruh jus apel dan susu tinggi kalsium rendah lemak terhadap kadar kolesterol total pada tikus Sprague Dawly hiperkolesterolemia.

Metode: Penelitian ini merupakan penelitian true experiment dengan pre-post test randomized control group design yang menggunakan 25 ekor tikus hiperkolesterolemia. Pengelompokan dilakukan secara acak menjadi 6 kelompok yaitu kelompok kontrol negatif yang hanya diberikan pakan standar, kontrol positif yang diberikan pakan standar dan tinggi kolesterol, dan empat kelompok perlakuan yang diberikan pakan standar, tinggi kolesterol dan intervensi berupa kombinasi jus apel dengan dan tanpa kulit 4,62 g dan susu tinggi kalsium rendah lemak 6,16 ml selama 14 hari. Serum kolesterol total sebelum dan sesudah perlakuan diperiksa menggunakan metode CHOD-PAP. Data dianalisis dengan uji Paired t-test, Wilcoxon dan Anova.

Hasil: Kadar kolesterol total darah pada kelompok $K$ - turun dari 51,8mg/dl menjadi 50,3mg/dl sedangkan pada kelompok K+ naik dari 37,8mg/dl menjadi 41,3mg/dl. Pemberian intervensi menyebabkan kadar kolesterol total darah pada kelompok P1, P3 dan P4 turun sedangkan P2 naik. Kadar kolesterol total darah pada kelompok P1 turun dari $51 \mathrm{mg} / \mathrm{dl}$ menjadi 46,3mg/dl, kelompok P3 turun dari 48,2mg/dl menjadi 42,4mg/dl dan kelompok P4 turun dari 46mg/dl menjadi 44mg/dl. Kadar kolesterol total darah pada kelompok P2 naik dari 50mg/dl menjadi 55,3mg/dl. Berdasarkan uji Annova tidak terdapat perbedaan signifikan pada perubahan kadar kolesterol total sebelum dan saat intervensi $(p=0,224)$.

Simpulan: Pemberian intervensi berupa kombinasi jus apel dengan kulit dan jus apel tanpa kulit pada dosis 4,62 $\mathrm{g}$ serta susu tinggi kalsium rendah lemak pada dosis 6,16 ml selama 14 hari tidak dapat menurunkan kadar kolesterol total darah.
\end{abstract}

\footnotetext{
${ }^{*}$ Penulis Penanggungjawab
} 
Kata kunci : jus apel fuji; susu tinggi kalsium rendah lemak; kolesterol total; hiperkolesterolemia

\section{PENDAHULUAN}

Penyakit kardiovaskuler merupakan penyebab kematian utama di dunia menurut World Health Federation 2004. ${ }^{1}$ Data WHO 2008 menunjukkan 17,3 juta orang meninggal karena penyakit kardiovaskuler dan $80 \%$ terjadi di negara dengan penghasilan rendah. ${ }^{2}$ Penyakit kardiovaskuler diperkirakan akan terus meningkat tiap tahunnya dan mencapai angka 23,3 juta pada tahun $20300^{2,3}$

Penyakit kardiovaskuler paling sering terjadi akibat aterosklerosis. ${ }^{4,5}$ Faktor risiko dari penyakit kardiovaskuler yang dapat diubah meliputi hipertensi, kebiasaan merokok, diabetes, gaya hidup sedenter, obesitas, peningkatan homosistein dan dislipidemia sedangkan yang tidak dapat diubah meliputi usia, jenis kelamin dan riwayat keluarga. ${ }^{4-6}$

Dislipidemia merupakan gangguan metabolisme lipid yang menyebabkan kadar lipid darah menjadi tidak normal yang biasanya ditandai dengan tingginya kolesterol total, trigliserida, low density lipoprotein (LDL) kolesterol dan rendahnya high density lipoprotein (HDL) kolesterol. ${ }^{1,4-6}$

Hiperkolesterolemia merupakan suatu keadaan dimana kolesterol total darah melebihi batas normal yaitu $>240 \mathrm{mg} / \mathrm{dl} .{ }^{6}$ Penelitian di United States menunjukkan pada tahun 2005-2006, $16 \%$ orang dewasa memiliki kadar total kolesterol $>240 \mathrm{mg} / \mathrm{dl}^{7}{ }^{7}$ Diet yang tepat, pola hidup yang sehat serta konsumsi sayuran dan buah-buahan dapat mengontrol dan menurunkan kadar kolesterol total. $^{8}$

Apel (Malus domestica) merupakan buahbuahan tinggi kandungan serat dan fitokimia terutama fenolik dan flavonoid. ${ }^{8}$ Senyawa flavonoid terbukti dapat menurunkan kadar kolesterol darah dan kejadian obesitas yang merupakan faktor risiko terjadinya kardiovaskuler dengan menurunkan penyerapan kolesterol. ${ }^{8-14}$

Beberapa studi menunjukan kandungan serat dan fitokimia apel berupa procyanidin, catechin, epicatechin dan quercetin berpengaruh positif menurunkan risiko penyakit vaskuler. ${ }^{8-10}$ Varietas apel fuji digunakan dalam penelitian ini karena memiliki kandungan fenolik dan flavonoid (catechin ekuivalen) yang paling banyak dibandingkan dengan varietas jenis red delicious, gala, liberty, northern spy, golden delicious, rome beauty, fortune, jonagold, idared, cortland, empire, NY647. Kandungan fenolik (gallic acid ekuivalen/100gr) pada apel fuji terbukti paling tinggi dengan kisaran 200-250mg dan kandungan fenolik terendah pada apel NY647 dengan kisaran 100-150mg. Kandungan flavonoid (catechin ekuivalen /100gr) pada apel fuji terbukti paling tinggi dengan kisaran 100-120mg dan kandungan flavonoid terendah pada apel empire dengan kisaran 40-60mg. ${ }^{8}$

Kandungan fitokimia pada apel bervariasi antara kulit dan daging buah. Apel bila dikonsumsi bersama dengan kulit memiliki kandungan fitokimia dan aktivitas antioksidan yang lebih banyak daripada tanpa kulit. ${ }^{8-9}$ Kulit apel memiliki kandungan fenolik total 1,2-3,3 kali lebih besar dan mengandung aktivitas antioksidan 1,5-9,2 kali lebih besar dibandingkan dengan daging buah. ${ }^{8}$

Susu dan produk susu merupakan sumber terbaik kalsium. Beberapa penelitian membuktikan kalsium dapat mempengaruhi berat badan maupun kadar lemak tubuh. Kandungan susu rendah lemak dianggap paling baik bekerja bersama dengan kalsium dalam mempengaruhi jaringan adiposa dan perubahan penyerapan lemak karena whey protein yang merupakan komponen produk susu dapat bekerja secara sinergis dengan kalsium untuk mengganggu metabolisme lipid. . $^{2-16}$

Penelitian mengenai efek apel dan susu masing-masing sudah beberapa kali dilakukan. Penelitian dilakukan untuk lebih mendalami dan mengembangkan kombinasi antara jus apel dengan susu tinggi kalsium rendah lemak dalam mempengaruhi kolesterol total. Apel di berikan dalam bentuk jus untuk memudahkan proses intervensi. ${ }^{11}$ Tikus jantan Rattus norvegicus galur Sprague Dawley digunakan dalam penelitian karena dianggap lebih sensitif terhadap perlakuan dan lebih mudah dikerjakan. ${ }^{20}$

\section{METODE PENELITIAN}

Penelitian true experimental dengan prepost test randomized control group design ini dilakukan di Laboratorium Parasitologi Fakultas Kedokteran Universitas Diponegoro (UNDIP) Semarang dengan perlakuan pemberian jus apel fuji (Malus Domestica) dan susu tinggi kalsium rendah lemak pada sampel tikus. Hasil yang dianalisis dalam penelitian ini ialah kadar kolesterol total, berat badan dan asupan.

Sampel tikus yang digunakan yaitu tikus Sprague Dawley jantan berusia 8 minggu dengan berat badan 150-180 gram yang diperoleh dari Laboratorium Farmasi Universitas Gajah Mada, 
Yogyakarta. Penentuan jumlah sampel minimal berdasarkan rumus Federer ialah 4 ekor tiap kelompok. Pada awal penelitian menggunakan 5 ekor tikus tiap kelompok untuk mengantisipasi apabila terdapat tikus yang mati saat perlakuan. Penelitian ini menggunakan 6 kelompok perlakuan sehingga jumlah sampel yang digunakan sebanyak 30 ekor. Selama penelitian, terdapat 5 ekor tikus yang drop out pada kelompok $\mathrm{K}-, \mathrm{K}+, \mathrm{P} 1, \mathrm{P} 2$ dan P4 sehingga jumlah sampel yang digunakan selama penelitian sebanyak 4 ekor pada kelompok $\mathrm{K}-\mathrm{K}+$, P1, P2, P4 dan 5 ekor pada kelompok P3 sesuai dengan jumlah sampel minimal.

Kelompok dalam penelitian ini yaitu kelompok kontrol negatif (K-), kontrol positif $(\mathrm{K}+)$, kelompok perlakuan 1 dan 3 mendapat pakan standar, pakan tinggi kolesterol dan 4,62g jus apel dengan kulit. Kelompok perlakuan 2 dan 4 mendapatkan pakan standar, pakan tinggi kolesterol dan 4,62g jus apel segar tanpa kulit. Kelompok perlakuan 3 dan 4 mendapat tambahan susu tinggi kalsium rendah lemak $6,16 \mathrm{ml}$. Kelompok kontrol negatif hanya diberikan pakan standar. Kelompok kontrol positif diberikan pakan standar dan pakan tinggi lemak, sedangkan kelompok perlakuan 1, 2, 3 dan 4 diberikan sama seperti kelompok kontrol positif. Seluruh subjek diberikan pakan standar BR-2 sebanyak 20 gram per hari serta minum air ad libitum. Selama penelitian dilakukan penimbangan berat badan dan sisa pakan serta pembersihan kandang.

Sebelum intervensi, dilakukan perlakuan untuk membuat kondisi hiperkolesterolemia pada hewan coba kelompok kontrol positif dan kelompok perlakuan dengan pemberian pakan tinggi kolesterol dari otak sapi selama 2 minggu. Otak sapi dipilih sebagai pakan tinggi kolesterol dan diberikan $2 \mathrm{ml} /$ hari. Otak sapi yang diberikan merupakan otak sapi yang telah dikukus dan diblender. Otak sapi diberikan dengan perbandingan penambahan air 1:1 untuk memudahkan proses sonde. ${ }^{22}$
Pembuatan jus apel dilakukan dengan mencuci dan memotong apel menjadi beberapa bagian. Apel ditimbang sesuai dosis dan jumlah tikus kemudian diblender. Apel yang sudah diblender kemudian diletakkan ke dalam wadah dan ditimbang sesuai dosis $(4,62 \mathrm{~g} /$ ekor/hari). Jus apel kemudian disaring menggunakan saringan buah. Sari apel diberikan kepada tikus melalui sonde sedangkan ampas apel dicampurkan pada makanan.

Apel di jus dengan 2 cara yaitu dengan kulit dan tanpa kulit. Perlakuan 1 dan 3 menggunakan apel yang di jus bersama dengan kulitnya sedangkan perlakuan 2 dan 4 menggunakan apel yang di jus tanpa kulit.

Susu yang digunakan merupakan susu tinggi kalsium rendah lemak yang dapat diperoleh di pasaran dengan merk $\mathrm{X}$ dengan syarat kemasan rapat, tidak penyok dan tidak kadaluarsa. Susu diberikan $6,16 \mathrm{ml} /$ ekor/hari diberikan dalam 2 kali penyajian.

Pengambilan darah dilakukan sebanyak dua kali yaitu sebelum dan sesudah intervensi untuk melihat pengaruh pemberian intervensi pada kadar kolesterol total tiap kelompok hewan coba. Sampel darah diambil pada bagian pleksus retro orbitalis oleh petugas laboratorium sebanyak $2 \mathrm{ml}$. Sampel darah tersebut diletakkan pada tabung dan di pisahkan antara darah dan serum melalui proses sentrifuge. Serum darah kemudian digunakan untuk mengukur kadar kolesterol total. Kadar kolesterol total diperiksa menggunakan metode CHOP-PAP.

Data yang diperoleh diolah dengan program komputer. Data diuji normalitasnya menggunakan uji Shapiro-Wilk. Perbedaan kadar kolesterol total sebelum dan setelah pemberian jus apel fuji (Malus Domestica) dan susu tinggi kalsium rendah lemak menggunakan uji Paired $t$ test dan Wilcoxon. Perbedaan perubahan kadar kolesterol total antar keempat kelompok perlakuan dianalisis menggunakan uji Anova. ${ }^{23}$ 


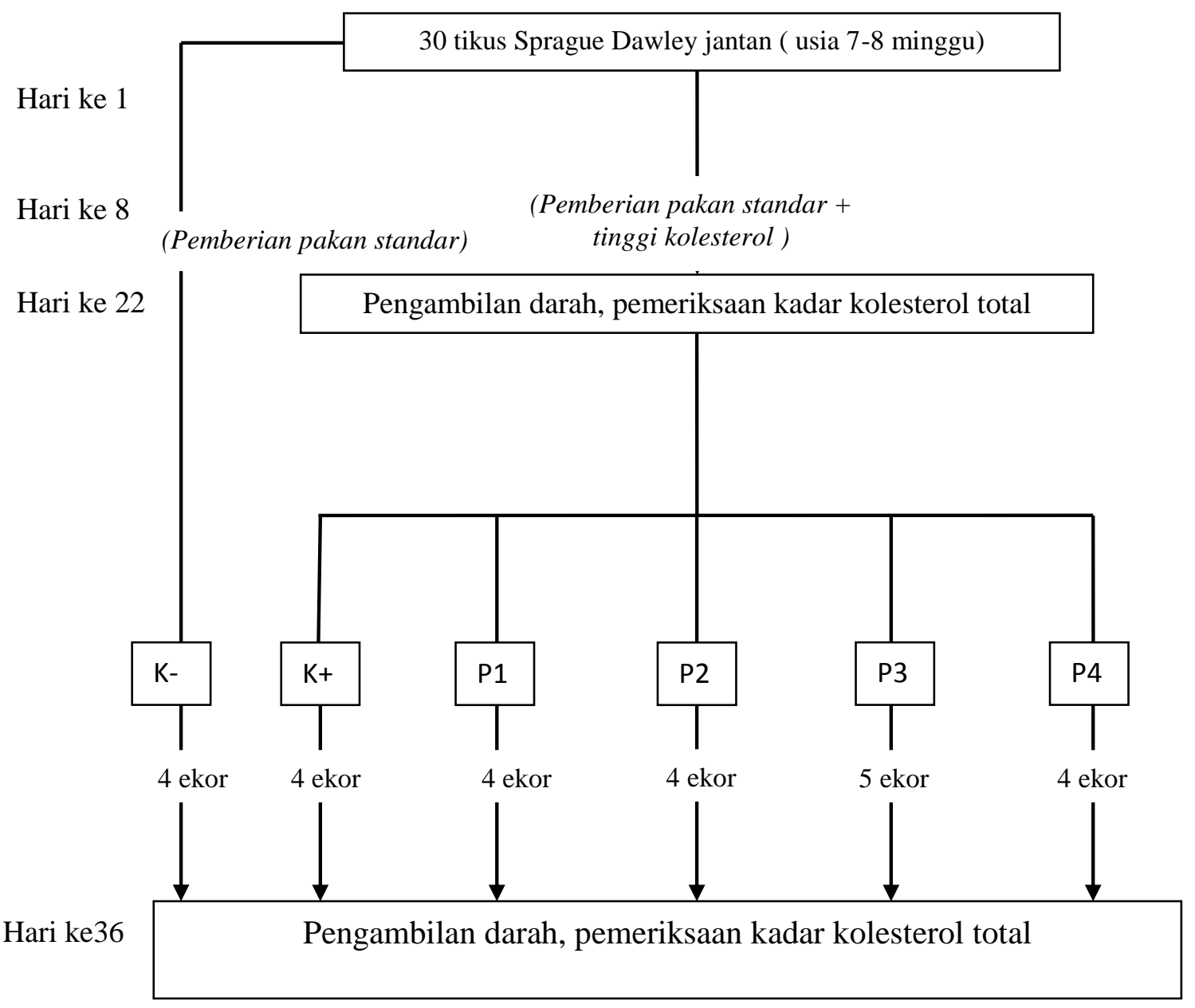

Gambar 1. Bagan Alur Penelitian

\section{HASIL PENELITIAN}

Jumlah sampel pada penelitian ini sebanyak 30 ekor kemudian dibagi menjadi 6 kelompok yaitu kelompok kontrol negatif (K-), kontrol positif $(\mathrm{K}+)$, kelompok perlakuan 1, kelompok perlakuan 2, kelompok perlakuan 3 dan kelompok perlakuan 4.

\section{Karakteristik Sampel}

Tiga puluh ekor tikus Sprague Dawley jantan dipelihara dalam kandang individu. Pemeliharaan dan pembersihan kandang dilakukan setiap hari oleh peneliti.

Penimbangan berat badan dilakukan 1 kali dalam seminggu sedangkan penimbangan sisa pakan dilakukan setiap hari selama penelitian.

Tabel 1. Hasil Analisis Rerata Berat Badan Sampel

\begin{tabular}{|c|c|c|c|c|c|c|}
\hline \multirow[t]{2}{*}{ Kelompok } & \multirow[b]{2}{*}{$\mathbf{N}$} & \multicolumn{2}{|c|}{ Berat Badan Tikus } & \multirow{2}{*}{$\begin{array}{c}\Delta \\
(\mathrm{g})\end{array}$} & \multirow[t]{2}{*}{$\% \Delta$} & \multirow[t]{2}{*}{$p$} \\
\hline & & $\begin{array}{l}\text { Sebelum }(g) \\
\text { Rerata } \pm \text { SD }\end{array}$ & $\begin{array}{l}\text { Setelah }(g) \\
\text { Rerata } \pm \text { SD }\end{array}$ & & & \\
\hline K- & 4 & $176,1 \pm 10,09$ & $219,7 \pm 18,94$ & $43,5 \pm 2,37^{\mathrm{a}}$ & 24,71 & $0,035^{\mathrm{b}} *$ \\
\hline $\mathrm{K}+$ & 4 & $182,0 \pm 7,96$ & $215,6 \pm 16,80$ & $33,6 \pm 9,39^{\mathrm{a}}$ & 18,45 & $0,336^{\mathrm{b}}$ \\
\hline P1 (apel+kulit) & 4 & $162,4 \pm 20,76$ & $194,0 \pm 28,15$ & $31,6 \pm 10,7^{\mathrm{a}}$ & 19,44 & $0,010^{\mathrm{b}} *$ \\
\hline P2 (apel) & 4 & $178,9 \pm 4,97$ & $209,8 \pm 6,65$ & $30,8 \pm 9,71^{\text {a }}$ & 17,23 & $0,008^{\mathrm{b} *}$ \\
\hline P3(apel+kulit+susu) & 5 & $181,6 \pm 8,18$ & $219,0 \pm 17,20$ & $37,4 \pm 24,75^{\mathrm{a}}$ & 20,60 & $0,043^{\mathrm{c}_{*}}$ \\
\hline P4(apel+susu) & 4 & $179,8 \pm 9,26$ & $212,8 \pm 9,91$ & $33,0 \pm 3,44^{\mathrm{a}}$ & 18,36 & $0,000^{\mathrm{b}} *$ \\
\hline
\end{tabular}

${ }^{\mathrm{a}} \mathrm{Uji}$ Anova

${ }^{\mathrm{b}}$ Uji Paired $t$-test *berbeda bermakna

${ }^{\mathrm{b}}$ Uji Wilcoxon *berbeda bermakna 
Bedasarkan data yang ditunjukkan pada tabel 1, peningkatan berat badan sebelum dan selama penelitian paling banyak terjadi pada kelompok perlakuan $\mathrm{K}$ - yaitu 43,5g karena kelompok perlakuan K- menghabiskan pakan yang relatif lebih banyak antara sebelum dan sesudah perlakuan.
Hasil analisis perubahan berat badan sampel yang diuji dengan uji Anova menunjukkan bahwa tidak terdapat perbedaan rerata berat badan antar kelompok perlakuan $(p=0,870)$. Berdasarkan uji Paired t-test tidak terdapat perbedaan bermakna pada kelompok perlakuan $(\mathrm{K}+)$.

Tabel 2. Hasil Analisis asupan pakan tikus sebelum dan sesudah perlakuan

\begin{tabular}{lllll}
\hline Kelompok & & \multicolumn{2}{c}{ Asupan Pakan } & $P$ \\
\cline { 2 - 4 } & N & $\begin{array}{l}\text { Sebelum } \\
\text { (g) }\end{array}$ & $\begin{array}{l}\text { Selama (g) } \\
\text { Rerata } \pm \text { SD }\end{array}$ & \\
\hline K- & 4 & $19,1 \pm 0,20$ & $19,1 \pm 0,19$ & $0,388^{\mathrm{a}}$ \\
K+ & 4 & $18,5 \pm 0,35$ & $19,0 \pm 0,07$ & $0,089^{\mathrm{a}}$ \\
P1 (apel+kulit) & 4 & $19,0 \pm 0,14$ & $19,0 \pm 0,07$ & $0,987^{\mathrm{a}}$ \\
P2 (apel) & 4 & $19,2 \pm 0,25$ & $19,1 \pm 0,09$ & $0,432^{\mathrm{a}}$ \\
P3(apel+kulit+susu) & 5 & $18,7 \pm 0,41$ & $17,4 \pm 0,16$ & $0,001^{\mathrm{a}} *$ \\
P4(apel+susu) & 4 & $18,5 \pm 0,44$ & $17,3 \pm 0,26$ & $0,013^{\mathrm{a} *}$ \\
\hline
\end{tabular}

${ }^{a}$ Uji Paired $t$-test $*$ berbeda bermakna

Bedasarkan data yang ditunjukkan dari tabel 2, asupan makanan sebelum dan selama intervensi paling tinggi adalah kelompok perlakuan K- dan P2. Asupan makanan sebelum dan selama intervensi pada kelompok perlakuan $\mathrm{K}$ - adalah 19,1g dan 19,1g sedangkan asupan makanan sebelum dan selama intervensi pada kelompok perlakuan P2 adalah 19,2g dan 19,1g. Berdasarkan uji Paired t-test terdapat perbedaan bermakna pada kelompok perlakuan 3 dan 4 .

Kadar kolesterol total Setelah Pemberian Pakan Tinggi Kolesterol

Hasil analisis perbedaan kadar kolesterol total kelompok $\mathrm{K}(-)$ dengan $(\mathrm{K}(+), \mathrm{P} 1, \mathrm{P} 2, \mathrm{P} 3, \mathrm{P} 4)$ yang diuji menggunakan Independent t-test menunjukkan tidak terdapat perbedaan yang bermakna antara kadar kolesterol total antar kelompok setelah pemberian pakan tinggi kolesterol $(p=0,91)$.

Kadar Kolesterol Total Sebelum dan Setelah Pemberian Jus Apel (Malus Domestica) dan susu tinggi kalsium rendah lemak

Tabel 3 menampilkan hasil analisis kadar kolesterol total sebelum dan setelah pemberian jus apel Fuji (Malus Domestica) dan susu tinggi kalsium rendah lemak yang diuji menggunakan Paired t-test dan Wilcoxon serta menampilkan hasil analisis perbedaan perubahan ( $\Delta$ ) kadar kolesterol total antar kelompok yang diuji menggunakan uji Anova.

Tabel 3. Hasil Analisis Kadar kolesterol total

\begin{tabular}{|c|c|c|c|c|c|c|}
\hline \multirow{2}{*}{ Kelompok } & \multirow{2}{*}{$\mathbf{N}$} & $\begin{array}{c}\text { Sebelum } \\
\text { Perlakuan }\end{array}$ & $\begin{array}{c}\text { Selama } \\
\text { Perlakuan }\end{array}$ & \multirow{2}{*}{$\underset{(\mathbf{m g} / \mathbf{d l})}{\operatorname{Rerata} \pm \mathrm{SD}}$} & \multirow[t]{2}{*}{$\% \Delta$} & \multirow{2}{*}{$\boldsymbol{P}$} \\
\hline & & $\begin{array}{c}\text { Rerata } \pm \text { SD } \\
(\mathrm{mg} / \mathrm{dl})\end{array}$ & $\begin{array}{c}\text { Rerata } \pm \text { SD } \\
(\mathbf{m g} / \mathbf{d l})\end{array}$ & & & \\
\hline K- & 4 & $51,8 \pm 9,43$ & $50,3 \pm 9,74$ & $-1,5 \pm 6,24^{\mathrm{a}}$ & $-2,89$ & $0,715^{b}$ \\
\hline $\mathrm{K}+$ & 4 & $37,8 \pm 3,20$ & $41,3 \pm 6,24$ & $3,5 \pm 4,65^{\mathrm{a}}$ & 9,27 & $0,197^{\mathrm{c}}$ \\
\hline P1 (apel+kulit) & 4 & $51,0 \pm 9,76$ & $46,3 \pm 3,78$ & $-4,8 \pm 9,71^{\mathrm{a}}$ & $-9,31$ & $0,273^{\mathrm{b}}$ \\
\hline P2 (apel) & 4 & $50,0 \pm 4,83$ & $55,3 \pm 4,19$ & $5,3 \pm 6,99^{\mathrm{a}}$ & 10,50 & $0,144^{\mathrm{c}}$ \\
\hline P3(apel+kulit+susu) & 5 & $48,2 \pm 9,36$ & $42,4 \pm 4,28$ & $-5,8 \pm 8,01^{\mathrm{a}}$ & $-13,68$ & $0,176^{\mathrm{b}}$ \\
\hline $\mathrm{P} 4($ apel+susu) & 4 & $46,0 \pm 9,49$ & $44,0 \pm 5,16$ & $-2,0 \pm 7,07^{\mathrm{a}}$ & $-4,35$ & $1,000^{\mathrm{b}}$ \\
\hline
\end{tabular}

${ }^{\mathrm{a}} \mathrm{Uji}$ Anova

${ }^{\mathrm{b}}$ Uji Paired t-test

${ }^{\mathrm{c}}$ Uji Wilcoxon 
Tabel 3 menunjukkan bahwa tidak terdapat perbedaan bermakna antara kadar kolesterol total sebelum dan setelah pemberian jus apel (Malus Domestica) dan susu tinggi kalsium rendah lemak $(p=0,224)$. Kadar kolesterol total pada kelompok P2 diharapkan mengalami penurunan namun pada penelitian ini mengalami peningkatan.

Secara deskriptif penurunan kadar kolesterol total terjadi pada kelompok P1, P3 dan P4. Penurunan kadar kolesterol kemungkinan terjadi karena pemberian intervensi. Penurunan tertinggi terdapat pada kelompok P3 yang diberi intervensi jus apel dengan kulit dan susu yaitu sebesar 5,8mg/dl.

\section{PEMBAHASAN}

\section{Kandungan Susu Tinggi Kalsium Rendah Lemak}

Susu yang digunakan merupakan susu tinggi kalsium rendah lemak yang dapat diperoleh di pasaran. Tiap $250 \mathrm{ml}$ susu mengandung lemak total $3 \mathrm{~g}$; lemak jenuh $0,5 \mathrm{~g}$; lemak trans $0 \mathrm{~g}$; kolesterol $0 \mathrm{mg}$; protein $7 \mathrm{~g}$; karbohidrat total $15 \mathrm{gr}$; vitamin E 8mg; vitamin C 50,9mg dan kalsium 398mg.

\section{Pakan Tinggi Kolesterol}

Pada penelitian ini pengkondisian tikus menjadi hiperkolesterolemia menggunakan pakan tinggi kolesterol yaitu otak sapi. Otak sapi dipilih sebagai pakan tinggi kolesterol karena setiap 100g otak sapi mengandung sekitar $2 \mathrm{~g}$ kolesterol dan $2,9 \mathrm{~g}$ asam lemak jenuh. ${ }^{25}$ Kondisi hiperkolesterolemia dapat dilihat dengan membandingkan kadar kolesterol total kelompok yang diberi pakan tinggi kolesterol $(\mathrm{K}(+), \mathrm{P} 1, \mathrm{P} 2$, P3 dan P4) dengan kelompok $\mathrm{K}(-)$ yang tidak mendapat pakan tinggi kolesterol. Kelompok K(-) berperan sebagai gambaran kadar kolesterol total tikus normal.

Hasil analisis perbedaan kadar kolesterol total antara kelompok $\mathrm{K}(-)$ dengan $\mathrm{K}(+)$, P1, $\mathrm{P} 2, \mathrm{P} 3, \mathrm{P} 4$ yang diuji menggunakan Independent $t$ test menunjukkan tidak terdapat perbedaan yang bermakna antara kadar kolesterol total antar kelompok setelah pemberian pakan tinggi kolesterol $(p=0,91)$. Kadar kolesterol total pada kelompok $\mathrm{K}(+), \mathrm{P} 1, \mathrm{P} 3$ dan P4 seharusnya lebih tinggi dibandingkan dengan kadar kolesterol total pada kelompok $\mathrm{K}(-)$ karena kelompok $\mathrm{K}(+), \mathrm{P} 1$, P2, P3 dan P4 mendapat pakan tinggi kolesterol. ${ }^{24}$ Pengkondisian hiperkolesterolemia pada penelitian ini tidak tercapai, hal ini dapat disebabkan karena kelompok perlakuan K- menghabiskan pakan yang relatif lebih banyak antara sebelum dan sesudah perlakuan yaitu $19,1 \mathrm{~g}$ dan $19,18 \mathrm{~g}$ dan mengalami peningkatan berat badan paling tinggi dibandingkan dengan semua kelompok yaitu $43,5 \mathrm{~g}$.

\section{Berat Badan dan Asupan Pakan Sampel}

Hasil uji Paired T-test dan wilcoxon pada berat badan sampel menunjukkan terdapat perbedaan berat badan sebelum dan setelah pemberian jus apel dan susu tinggi kalsium rendah lemak pada semua kelompok perlakuan kecuali kelompok $\mathrm{K}+$. Hal ini kemungkinan terjadi karena terdapat 2 ekor tikus pada kelompok $\mathrm{K}+$ yang sakit (berjamur dan berkutu). Rerata peningkatan berat badan sampel pada kelompok $\mathrm{K}(-), \mathrm{K}(+), \mathrm{P} 1, \mathrm{P} 2$, P3 dan P4 secara berurutan yaitu 43,5g; 33,6g; $31,6 \mathrm{~g} ; 30,8 \mathrm{~g} ; 37,4 \mathrm{~g}$ dan 33,0g. Jumlah asupan pakan sampel selama intervensi pada kelompok $\mathrm{K}(-), \mathrm{K}(+), \mathrm{P} 1, \mathrm{P} 2, \mathrm{P} 3$ dan $\mathrm{P} 4$ secara berurutan yaitu $19,18 \mathrm{~g} ; 19,0 \mathrm{~g} ; 19,0 \mathrm{~g} ; 19,1 \mathrm{~g} ; 17,4 \mathrm{~g}$; dan 17,3g. Hal ini menunjukkan bahwa semakin banyak jumlah asupan pakan maka semakin besar peningkatan berat badan sampel.

Kadar Kolesterol Total Sebelum dan Setelah Pemberian Jus Apel (Malus Domestica) dan Susu Tinggi Kalsium Rendah Lemak

Hasil dari penelitian ini menunjukkan terdapat perbedaan kadar kolesterol total antara sebelum dan setelah pemberian jus apel fuji (Malus Domestica) dan susu tinggi kalsium rendah lemak pada semua kelompok perlakuan. Hasil analisis perubahan kadar kolesterol total menunjukkan tidak terdapat perbedaan kadar kolesterol total antar kelompok $\mathrm{K}(-), \mathrm{K}(+), \mathrm{P} 1, \mathrm{P} 2$, P3 dan P4 $(p=0,224)$. Secara deskriptif kelompok P1, P3 dan P4 turun sedangkan P2 naik. Hal ini menunjukkan bahwa pemberian jus apel (Malus Domestica) dan susu tinggi kalsium rendah lemak dapat menurunkan kadar kolesterol total tikus Sprague Dawley hiperkolesterolemia namun secara statistik tidak signifikan.

Pada kelompok K(-) hanya diberikan pakan standar selama penelitian. Kadar kolesterol total pada kelompok $\mathrm{K}(-)$ mengalami sedikit penurunan yaitu $2,89 \%$. Seharusnya tidak terjadi perubahan kadar kolesterol total pada kelompok $\mathrm{K}(-)$ karena pada kelompok ini tidak diberikan perlakuan apa-apa.

Pada kelompok $\mathrm{K}(+)$ diberikan pakan standar dan pakan tinggi kolesterol. Kadar kolesterol total pada kelompok $\mathrm{K}(+)$ naik sebesar $9,27 \%$. Hal ini terjadi karena pakan tinggi kolesterol dapat meningkatkan kadar kolesterol total dalam darah. ${ }^{24}$ 
Jus apel dengan kulit dapat menurunkan kadar kolesterol total dalam darah dilihat dari perbandingan kadar kolesterol total pada kelompok P1 dan P2. Kelompok P1 yang diberikan intervensi berupa jus apel dengan kulit selama 14 hari turun kadar kolesterol total sebanyak 9,31\% sedangkan kelompok $\mathrm{P} 2$ yang diberikan intervensi berupa jus apel tanpa kulit naik sebesar 10,5\%.

Susu tinggi kalsium rendah lemak dapat menurunkan kadar kolesterol total dalam darah dilihat dari perbandingan kadar kolesterol total pada kelompok P4 dan P2. Kelompok P4 yang diberikan intervensi berupa jus apel tanpa kulit dan susu selama 14 hari mengalami sedikit penurunan yaitu sebesar 4,35\% sedangkan kelompok P2 yang tidak diberi susu tinggi kalsium rendah lemak naik sebesar $10,5 \%$.

Jus apel dengan kulit dan susu tinggi kalsium rendah lemak dapat menurunkan kadar kolesterol total dalam darah dilihat dari penurunan kadar kolesterol total yang paling tinggi terjadi pada kelompok P3 yaitu sebesar 13,68\%. Penyebab penurunan kadar kolesterol total pada kelompok perlakuan 3 diduga karena diberikan intervensi berupa jus apel dengan kulit dan susu tinggi kalsium rendah lemak.

Kulit apel memiliki kandungan serat (terutama pektin) dan fitokimia yang lebih banyak dari daging buah apel. ${ }^{8-10}$ Serat pektin pada apel dapat mempengaruhi penyerapan lemak karena dapat mengikat lebih banyak asam lemak dalam saluran pencernaan yang selanjutnya diekskresikan melalui feses. ${ }^{12}$ Pektin mempengaruhi sifat gel pada feses. Pektin lebih tahan terhadap hidrolisis oleh enzim pencernaan manusia dibandingkan selulosa (serat tidak larut). Pektin difermentasi oleh mikroflora dalam usus besar sehingga pembentukan asam lemak rantai pendek diserap dan dimetabolisme di kolon mukosa, hati, atau jaringan perifer. Serat larut pembentuk gel dapat menurunkan penyerapan kembali kolesterol dan asam empedu dalam usus bagian bawah, dan asam lemak rantai pendek yang dapat menurunkan biosintesis kolesterol pada hati. ${ }^{10,11}$

Kandungan procyanidin, catechin, epicatechin dan quecertin, pada apel memiliki aktivitas antioksidan yang kuat dan dapat menghambat oksidasi LDL kolesterol. ${ }^{8,9}$ Procyanidin berperan dalam menurunkan lipid darah dengan menghambat sintesis ester dan sekresi lipoprotein. ${ }^{11}$ Catechin dan epicatechin mengganggu sistem misel empedu dalam lumen usus dengan membentuk endapan larut dari kolesterol dan meningkatkan ekskresi fekal kolesterol. Ekskresi kolesterol fekal menurunkan penyerapan kolesterol dan konsentrasi kolesterol hati yang menyebabkan peningkatan ekspresi dan aktivitas reseptor LDL. ${ }^{9}$ Quecertin mengurangi produksi lipoprotein dan mengurangi peroksidasi lipid. ${ }^{8}$

Kalsium pada susu dapat mempengaruhi jaringan adiposa dan perubahan absorbsi lemak. Kalsium dapat secara langsung mempengaruhi simpanan jaringan adiposa dengan memecah lemak. Konsumsi makanan tinggi kalsium menurunkan kadar PTH dan 1,25-hidroxy vitamin $D$ yang menyebabkan penurunan kadar kalsium intraseluler dan menghambat lipogenesis serta menstimulasi lipolisis. Kadar kalsium yang tinggi dapat mengikat lebih banyak asam lemak pada usus kecil dan kolon sehingga akan diekskresikan melalui feses dan mengakibatkan terhambatnya penyerapan lemak. ${ }^{16-18}$

Asam lemak terhambat penyerapannya karena terikat oleh kalsium dalam usus kecil dan diekskresikan dalam feses. Terhambatnya penyerapan asam lemak mempengaruhi konsentrasi serum lipid dan profil asam lemak empedu. Konsentrasi serum lipid dan profil asam lemak empedu yang rendah menurunkan terjadinya hiperkolesterolemia yang merupakan salah satu risiko penyakit jantung. ${ }^{21}$

Kadar kolesterol total pada kelompok P2 yang diberi intervensi berupa jus apel tanpa kulit selama 14 hari pada penelitian ini naik sebesar $10,5 \%$. Hal ini kemungkinan terjadi karena ratarata asupan pada sebelum dan sesudah perlakuan yang tinggi yaitu $19,17 \mathrm{gr}$ dan 19,08gr serta kandungan zat pada jus apel yang diberikan tanpa kulit kurang efektif dalam menurunkan kadar kolesterol total darah pada tikus yang diberi pakan tinggi kolesterol. ${ }^{24}$

\section{SIMPULAN}

Pemberian intervensi berupa kombinasi jus apel dengan kulit dan jus apel tanpa kulit pada dosis 4,62 g serta susu tinggi kalsium rendah lemak pada dosis $6,16 \mathrm{ml}$ selama 14 hari tidak dapat menurunkan kadar kolesterol total darah.

\section{UCAPAN TERIMA KASIH}

Puji syukur kepada Allah SWT, terima kasih kepada Profesor dr.H M.Sulchan, MSc. DA. Nutr., SpGK selaku pembimbing dan para reviewer yang telah membimbing penelitian ini hingga dapat terlaksana sampai akhir. Selain itu terima kasih kepada orang tua dan teman-teman atas dukungan 
yang telah diberikan selama penelitian ini berlangsung.

\section{DAFTAR PUSTAKA}

1. Omole J.O and Ighodaro O.M.. Comparative studies of the effect of egg yolk, oats, apple, and wheat bran on serum lipid profile of wistar rats. ISRN Nutrition, 2013

2. World Health Organization,WHO Report 2011, Geneva: WHO,2011.

3. Buku ajar ilmu penyakit dalam jilid III edisi 1V page: 1919; Jakarta 2006

4. Price, Sylvia A. \& Wilson LM. Patofisiologi: Konsep Klinis Proses-Proses Penyakit. Edisi 6. Volume 2. Penerbit Buku Kedokteran Jakarta:EGC;2006

5. Krummel DA. Medical Nutrition Therapy in Cardiovascular Disease. In Mahan LK, Escottstump S. Krause's food, Nutrition, and Diet Therapy $12^{\text {th }}$ edition. Philadelphia: WB Saunders Company ; 2008

6. Schober SE, Carroll MD, Lacher DA, and Hirsch R. High Serum Total Cholesterol - An Indicator for Monitoring Cholesterol Lowering Efforts: U.S. Adults, 2005-2006. NCHS Data Brief 2007

7. Stapleton PA, Goodwill AG, James ME, et al. Review of Hypercholesterolemia and microvascular dysfunction: interventional strategies. Stapleton et al. Journal of Inflammation 2010, 7:54

8. Boyer $\mathbf{J}$ and Liu RH. Apple phytochemicals and their health benefit. BioMed Central 2004

9. Horticulture Australia Limited (HAL) The 2010 apple report, 2010

10. Jensen EN, Andersen TB, Haren GR, et al. Minireview: The effects of apples on plasma cholesterol levels and cardiovascular risk - a review of the evidence. Journal of Horticultural Science \& Biotechnology (2009)

11. Nouri MK and Rezapour AK. Effect of Apple (Malus domestica) supplementation on serum lipids and lipoproteins level in cholestrol-fed male rat middle-east J. Sci. Res., 9 (6): 744, 2011

12. Setorki M, Asgary S, Eidi1, et al. Effects of apple juice on risk factors of lipid profile, inflammation and coagulation, endothelial markers and atherosclerotic lesions in high cholesterolemic rabbits. Lipids in Health and Disease 2009, 8:39

13. Vafa MR, Haghighatjoo E, Shidfar F, et al. Effects of apple consumption on lipid profile of hyperlipidemic and overweight men. Int J Prev Med 2011; 2(2): 94

14. Veberic R, Trobec M, Herbinger K, et al. Phenolic compounds in some apple (Malus domestica Borkh) cultivars of organic and integrated production. J Sci Food Agric 85:1687 (2005) DOI: $10.1002 /$ jsfa. 2113
15. Gropper S.S., Smith J.L., and Groff G.L. Advanced Nutrition and Human Metabolism, $4^{\text {th }}$ ed. Thomson Wadsworth:2005

16. Schrager Sarina, M. Dietary calcium intake and obesity. J Am Board Fam Pract 2005;18:205

17. Weaver CM , Campbell WW, Teegarden D et al. Calcium, dairy products, and energy balance in overweight adolescents: a controlled trial. Am J Clin Nutr 2011;94:1163

18. Shahar DR, Schwarzfuchs D, Fraser D, at al. Dietary calcium, dairy calcium intake, serum vitamin D, and successful weight loss Am J Clin Nutr doi: 10.3945/ajen.2010.29355

19. Wennersberg MH, Smedman A, Turpeinen AM, et al. Dairy products and metabolic effects in overweight men and women:result from a 6-mo intervention study. Am J Clin Nutr 2009;90:960

20. Sprague Dawley. Harlan laboratories report 2008

21. Shaw SR, Nihal M and Ahmad N. Dose translation from animal to human studies Revisited. FASEB J. 22, 659 (2007)

22. Pratama Sandy E. Pengaruh pemberian kefir susu sapi terhadap kadar kolesterol LDL tikus jantan Sprague Dawley hiperkolesterolemia. Medical Faculty of Diponegoro University. Semarang: 2012

23. Dahlan MS. Statistik untuk kedokteran dan kesehatan. Ed3. Jakarta: Salemba Medica; 2001.hal 3

24. Araujo TG, Leite ACR, Fonseca CSM et al. Highfat diet based on dried bovine brain: an effective animal model of dyslipidemia and insulin resistance. J Physiol Biochem (2011) 67:371 